\title{
Production of Biodiesel from Waste Cooking Oil using Cao-Egg Shell Waste Derived Heterogeneous Catalyst
}

\author{
Israa M. Rashid ${ }^{1}$, Mohammed A. Atiya ${ }^{2}$, B. H. Hameed ${ }^{3}$ \\ ${ }^{1,2}$ Biochemical Engineering Department, Al-Khwarizmi Collage of Engineering, University of Baghdad, Baghdad 47024 Iraq \\ ${ }^{3}$ School of Chemical Engineering, Engineering Campus, University Sains Malaysia, 14300 Nibong Tebal, Penang, Malaysia
}

\begin{abstract}
Biodiesel is an environmentally friendly fuel and a good substitution for the fossil fuel. However, the purityof this fuel is a major concern that challenges researchers. In this study, a calcium oxide based catalyst has been prepared from local waste eggshells by the calcination method and tested in production biodiesel. The eggshells were powdered and calcined at different temperatures (700, $750,800,850$ and $900{ }^{\circ} \mathrm{C}$ ) and periods of time (1, 2, 3, 4 and $5 \mathrm{hr}$.). The effect of calcination temperature and calcination time on the structure and activity of the solid catalyst were examined by X-ray Diffraction (XRD), Scanning Electron Microscopy (SEM), and Brunaure-Emmett-Teller (BET). The optimum catalyst performance was obtained at $900{ }^{\circ} \mathrm{C}$ and $3 \mathrm{hr}$. The characterization tests revealed a crystalline phase of $\mathrm{CaO}$, a specific surface area $12.5 \mathrm{~m} 2 / \mathrm{gm}$ and good distribution of the active component. The effects of different transesterification reaction variables on the catalyst performance were also investigated. The highest conversion, $96.11 \%$ was obtained at 30:1 methanol-to-waste cooking oil molar ratio, $65^{\circ} \mathrm{C}, 3$ wt. \% catalyst loading and 3 hr reaction time. Additionally, durability of $\mathrm{CaO}$ was examined. It was found that high activity and durability were obtained by washing with $n$ hexan. It found that the use of eggshell as a heterogeneous catalyst for biodiesel production provides a cost-effective and environmentally friendly way of green fuel production.
\end{abstract}

Keywords: eggshells, $\mathrm{CaO}$, biodiesel, transesterification, heterogeneous catalyst

\section{Introduction}

The search for alternative sources of fuel to replace fossil fuel is currently attracting the attention of numerous scientists and fuel business owners. The substantial use of fossil fuel is depleting its reserve and emitting high concentration of air pollutants[1]. The insufficiency of fossil fuel has made renewable fuel an attractive topic of research because of growing demand of fuel worldwide. Recently, several types of alternative fuels were considered for the production and quality improvement.

Biodiesel fuel is an encouraging alternative fuel since it is renewable, biodegradable, meets the environmental standards and comparable to combustion properties of fossil diesel fuel. It shows a flash point higher than the conventional diesel. Thus, proved as green fuel, it is very close to zero emission of $\mathrm{CO}_{2}$ [2]. Biodieselcomposed of fatty acid methyl esters (FAMEs) are commonly produced from vegetable oils and animal fats. However, all edible vegetable oils demand a high cost of production, which is the main hindrance towards commercialization of biodiesel since the feedstock cost contributes to the overall project cost. A low cost vegetable oils, such as waste oil and nonedible oil, are considered as feedstocks, but their sustainability is of concerns due to the limited quantity of production [3] . Also waste oils and fats (used cooking oils) are used as a good feedstock, its costs approaches half of the cost of virgin oil[4]. Additionally, the use of waste fried cooking oil (WFCO) as a reactant for biodiesel plant helps in disposing this waste and reduction of feedstock production cost [5]. Thus, the engineering designers generally aim to develop a cost effective process that produces a commercialquality product at an optimum rate of production [6]

The FAMEs blend or biodiesel is produced through a catalytic transesterification reaction of a triglyceride feedstock and methanol. Several types of oils have been widely used a while for production of biofuel such as corn oil, soybeans oil, sunflower oil, coconut oil, tobacco seed oil, palm oil and sugarcane oil, and animal fats [7]. The chemical reaction is reversible as shown in equation 1 ; therefore, an alcohol compound is used in excess to drive the equilibrium to the FAMEs side. The transesterification reaction is promoted by this excess and facilitates the desorption of products from the catalyst surface to regenerate the active catalytic sites [ $\underline{8}]$.
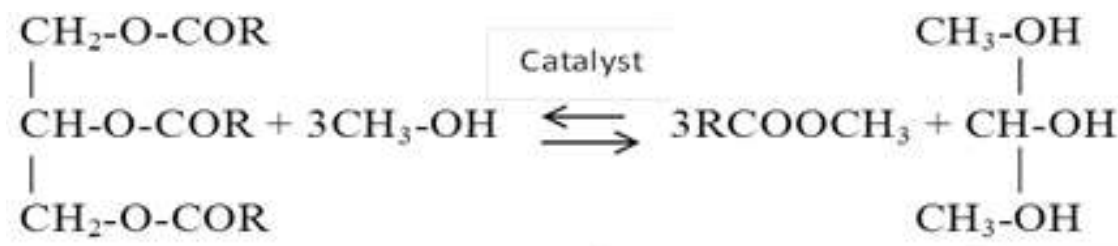

Triglycerid Methanol

Fatty acid Methyl ester Glycerol (Biodiesel)

Volume 6 Issue 11, November 2017 www.ijsr.net 


\section{International Journal of Science and Research (IJSR) \\ ISSN (Online): 2319-7064}

Index Copernicus Value (2015): 78.96 | Impact Factor (2015): 6.391

It is observed that methanol is the most appropriate alcohol used for this process from the economic and the available resources point of view. Moreover, methanol provides a higher reaction rate than ethanol and propanol [9]. Several catalysts have been applied and evaluated in biodiesel production and have proven the benefits of catalytic transesterification reaction over the non-catalytic process [10]. Catalysts used for transesterification are either homogeneous or heterogeneous. Homogeneous transesterification is the easiest process; however, it encompasses the intricacies of separation and purification of product because of the homogeneous nature of the reaction mixture (reactant, catalyst and product). It also is more likely to form soap which requires more washing and tends to form emulsions in the mixture. All these process complexities result in high production costs. Therefore, heterogeneous catalysts are the catalysts of the choice for biodiesel production nowadays because they overcome some of the drawbacks of homogeneous catalyst process. Additionally, they exhibit high catalytic activity, selectivity, their lifetime is long, and have a high tolerance to water and free fatty acids [11].

Over the last decade, different acidic and basic solid catalysts have been innovated for biodiesel products $[\underline{5}, \underline{12}, \underline{13}] . \mathrm{CaO}$ based catalyst is one of the most widely studied systems for biodiesel production because of its high activity, low production cost and availability [14]. Moreover, calcium oxide is a high basic catalyst, noncorrosive and can be synthesized from waste materials consisting of $\mathrm{CaCO}_{3}$, such as eggshells, mollusk and cockle. Being used as a $\mathrm{CaO}$ catalyst not only represents a cost effective method of biodiesel production, but also offers a good way to recycle the natural mineral resources, which meets the environmental regulations, and make the catalytic biodiesel process an environmentally friendly fuel production $[\underline{15}, \underline{16}]$.

Numerous studieshave focused on the application of $\mathrm{CaO}$ as a catalyst and they reported successful production in the last decade, Tan et al.[14] studied the use of ostrich egg shells to prepare a $\mathrm{CaO}$ catalyst and its application in the transesterification of soybean oil using a 12:01 methanol to oil ratio, a reaction time of 3 hours, $8 \%$ of $\mathrm{CaO}$ per oil mass and they obtained $96 \%$ yield with the calcined shells. Piker et al. [15] conducted the same reaction with a fresh soybean oil and yielded $97 \%$ of FAMEs at a molar ratio of 1:6 and $5.8 \%$ of $\mathrm{CaO}$ catalyst. Viola et al. [17] conducted transesterification of WFCO on three different catalyst $\mathrm{CaO}$, $\mathrm{SrO}$, and $\mathrm{K} 3 \mathrm{PO} 4$ and achieved $92 \%$ in 3 hours, $5 \% \mathrm{CaO}$ per oil $(\mathrm{m} / \mathrm{m})$ at $65{ }^{\circ} \mathrm{C}$ and a methanol to oil molar ratio of $6: 1$. Sirisomboonchai et al [19] studied transesterification of WCO by using calcined scallop shells as a catalyst with a loading amount of $5 \mathrm{wt} \%$ at $65{ }^{\circ} \mathrm{C}$ and they yielded $86 \%$. Pandit and Fulekar [20] utilized waste chicken egg shells for the synthesis of $\mathrm{CaO}$ nanocatalyst to transesterify dry biomass into biodiesel and reported a yield of $86.41 \%$. Teo et al [21] prepared a nanocatalyst derived from the waste eggshell of Gallus to produce biodiesel and applied neural network model to obtain a predicted yield of $97 \%$ at $60{ }^{\circ} \mathrm{C}$ and 5 hours reaction time. Viriya-empikul [22] derived a $\mathrm{CaO}$ catalyst from waste shells of eggs, golden apple snail, and meretrix venus and applied them in a transesterification of palm olein oil and obtained $90 \%$ yield at $60{ }^{\circ} \mathrm{C}$ and $2 \mathrm{hrs}$. Boro et al. [23] applied a series of Li doped egg shell derived $\mathrm{CaO}$ to produce biodiesel from nonedible oil feedstock and obtained a conversion of $94 \%$ with $5 \%$ of catalyst loading and $2 \%$ of Li. Niju et al. [24] exposed the waste egg shells to calcination-hydration-dehydration treatment to improve $\mathrm{CaO}$ activity with high activity in transesterification of WFCO. They applied the catalyst at 5 $\%$ loading, a methanol to oil ratio of $12: 1$, a temperature of $65{ }^{\circ} \mathrm{C}$ and one hour to obtain $94.52 \%$ with the prepared catalyst compared to $67.57 \%$ with the commercial one. Chen [25] used an ultrasonic source to excite the transesterification of palm oil over a $\mathrm{CaO}$ catalyst derived from waste egg shell to reach $92.7 \%$ at $60 \mathrm{~min}$, methanol-tooil ratio of $9: 1$, and catalyst loading of $8 \mathrm{wt} . \%$. Gupta et al [26] used a pure $\mathrm{CaO}$ compound, prepared their own catalyst and applied it in the presence of ultrasound to yield a $93.5 \%$ biodiesel , they also used WFCO Also, there are several review articles prepared by Kouzu et al [9], Boey et al [ㅁ], Kesic et al [18] and Tan et al. [27]which showhow the use $\mathrm{CaO}$ catalyst is advantageous in biodiesel production. The present study focuses on the effect of calcination temperature of the $\mathrm{CaO}$ catalyst derived from local egg shells on improving of conversion of WFCO via a transesterification reaction and reduction of reaction time. Different operating conditions are examined to overcome the drawback of the previous studies that involves low quality of biodiesel, long time of reaction and high cost of commercial catalyst.

\section{Materials and methods}

\subsection{Materials}

The feedstock of this experiment, WCSO, was collected from a cafeteria at the Alkhawarizmi Engineering College, Baghdad University, Iraq. Prior to use, the WCSO was filtered to get rid of all insoluble impurities and moisture was removed by heating at $120^{\circ} \mathrm{C}$ for $2 \mathrm{~h}$. The composition of fatty acids contained in the WCSO were determined by chromatography in GCMS (DANI; Master, European) equipped with a capillary column $(30 \mathrm{~m} \times 0.25 \mathrm{~mm} \times 0.25$ $\mathrm{mm}$ ) as shown in Table 1 and the physiochemical properties were measured and presented in Table 2. The waste eggshells were collected from the same cafeteria. Methanol (HPLC grade, 99.9\%), used for transesterification; n-hexane (HPLC grade, 99\%), used as solvent for gas chromatography (GC), and methyl heptadecanoate (purity 99\%), used as internal standard for GC, were purchased from SigmaAldrich.

Table 1: Fatty acid composition of waste cooking sunflower oil

\begin{tabular}{|c|c|}
\hline Fatty acid & Composition \\
\hline Oleic acid (C18:1) & 34.97 \\
\hline Heptadecanoic acid (C17:0) & 30.75 \\
\hline Palmitic acid (C16:0) & 21.12 \\
\hline Linolenic acid (C18:3) & 2.66 \\
\hline n-pentadecanoic acid (18:0) & 1.61 \\
\hline Linoleic acid (C18:2) & 1.61 \\
\hline Arachidic acid(C20:0) & 1.61 \\
\hline Myristic acid (C14:0) & 0.86 \\
\hline
\end{tabular}

\section{Volume 6 Issue 11, November 2017}




\section{International Journal of Science and Research (IJSR) \\ ISSN (Online): 2319-7064}

Index Copernicus Value (2015): 78.96 | Impact Factor (2015): 6.391

\begin{tabular}{|c|c|}
\hline Eicosadienoic acid (C20:2) & 0.66 \\
\hline Lauric acid (C12:0) & 0.19 \\
\hline Palmitoleic acid (C16:1) & 0.18 \\
\hline Others & 3.78 \\
\hline
\end{tabular}

Table 2: Physiochemical properties of waste cooking sunflower oil

\begin{tabular}{|c|c|}
\hline Property & Measured value \\
\hline Molecular weight & 855.8914 \\
\hline Density at $25^{\circ} \mathrm{C}(\mathrm{kg} / \mathrm{m} 3)$ & 910 \\
\hline viscosity at $40^{\circ} \mathrm{C}(\mathrm{cp})$ & 38.7 \\
\hline Acid value $(\mathrm{mg}$ of $\mathrm{KOH} / \mathrm{g}$ of oil $)$ & 1.7 \\
\hline
\end{tabular}

\subsection{Catalyst Preparation}

The waste eggshells were used as a precursor of $\mathrm{CaO}$ in this study. To remove all unwanted materials adhered to the surface, they were washed thoroughly with tap water and rinsed several times with deionized water. After being cleaned, the eggshells were sun dried. The dry eggshells were crushed and sieved in 75 mesh sieve set. The dried powder was calcined in a muffle furnace at different temperatures $\left(700,750,800,850\right.$, and $\left.900^{\circ} \mathrm{C}\right)$ and periods of times $(1,2,3,4$, and $5 \mathrm{hr})$ to determine the optimum calcination conditions.

\subsection{Catalyst characterization}

The waste shells were examined by using a scanning electron microscope (SEM: TESCAN, Vega III, Czech Republic) toemphasize the morphology of catalyst. The crystalline structure of catalyst was analyzed by X-ray diffraction (XRD: XRD-6000, shimadzu, Japan). The surface area and pore volume properties were calculated based on the nitrogen adsorption-desorption isotherm using the apparatus of Brunaure-Emmett-Teller (BET: HORIBA, SA-900 series, USA).

\subsection{Catalytic reaction and product analysis}

The transesterification of WCSO with methanol was carried out in a $500 \mathrm{ml} \mathrm{3-necked} \mathrm{round} \mathrm{bottomed} \mathrm{flask} \mathrm{with} \mathrm{a}$ mechanical stirrer (PHOENX, RSO 20D) and equipped with a reflex condenser. $30 \mathrm{ml}$ of WCSO was heated to $60^{\circ} \mathrm{C}$ then a certain amount of methanol was added based on different methanol to oil ratio. Different weights of catalystwere loaded to the flask and all were heated and brought to the desired temperature by mixing at $300 \mathrm{rpm}$.

Perfect mixing also provides contacts of reactants, WCSO and methanol, with $\mathrm{CaO}$ catalyst. In order to determine the optimum operating conditions of the transesterification, the following parameters are examined,

1) methanol: oil ratio: 9:1, 12:1, 20:1, 30:1, 36:1, and 40:1;

2) catalyst loading: $1,2,3,4,5$, and $6 \mathrm{wt} \%$;

3) reaction time: $2,3,4$, and $5 \mathrm{hr}$;

4) temperature $\left(55^{\circ} \mathrm{C}, 60{ }^{\circ} \mathrm{C}, 65^{\circ} \mathrm{C}\right.$, and $\left.70{ }^{\circ} \mathrm{C}\right)$.

At the end of the reaction, the liquid products were collected and cooled to room temperature. The liquid mixturewas composed of methyl ester, methanol, and glycerol was decanted for $24 \mathrm{~h}$. FAMEs which were the upper phase were analyzed by GC according to EN 14103[28]. The GC was equipped with a flame ionization detector (FID-2010 Plus) and a capillary column (DN-WAX; length: 30m, ID: 0.32 $\mathrm{mm}$, and film thickness: $1 \mu \mathrm{l})$. Methyl heptadecanoate was used as an internal standard. A sample of $1 \mu$ volume was injected and the FAME composition was calculated by the following equation [28]:

$$
\mathrm{FAME} \%=\frac{\sum A-A_{E I}}{A_{E I}} \times \frac{C_{E I} \cdot V_{E I}}{m} \times 100
$$

$\sum A$ : total peak areas of the methyl ester in C14 of that in C24:1;

AEI: peak of methyl heptadecanoate;

CEI: concentration of the methyl heptadecanoate solution $(\mathrm{mg} / \mathrm{ml})$

VEI: volume of the methyl heptadecanoate solution (ml); M: weight of the sample (mg).

\subsection{Catalyst reusability and stability}

After completion of the transesterification reaction employed at the optimal conditions, the catalyst was collected from the reactant mixture by filtration; the catalyst was washed with hexane several times to remove the adhered oil particles, and then dried at $110^{\circ} \mathrm{C}$ for $2 \mathrm{hr}$. The catalyst was reused several times without further treatment to obtain FAME from WCSO.

To evaluate catalyst stability, the optimum amount of $\mathrm{CaO}$ that was obtained by examining the operating condition was stirred with $38 \mathrm{ml}$ methanol at the optimum conditions obtained. After the catalyst was separated, methanol was mixed with $30 \mathrm{ml}$ WCSO and the reaction was carried out under the optimum conditions, $65^{\circ} \mathrm{C}$, methanol: oil ratio $30: 1,3 \mathrm{hr}$. and $300 \mathrm{rpm}$.

\section{Results and discussion}

\subsection{Catalyst characterization}

The synthesized $\mathrm{CaO}$ catalyst was subjected to different temperatures and times of calcination. The calcination time and temperature changed the catalyst structure; consequently, this affects catalyst activity andthe concentration of FAMEs produced. The impact of different calcination temperatures, $700{ }^{\circ} \mathrm{C}, 750{ }^{\circ} \mathrm{C}, 800{ }^{\circ} \mathrm{C}, 850{ }^{\circ} \mathrm{C}$, and $900{ }^{\circ} \mathrm{C}$, and durations, $1,2,3,4$, and $5 \mathrm{hr}$, were tested for the transesterification of WCSO to produce biodiesel. The eggshell powder showed an apparent color different from the color before calcination as shown in Figure 1. Table 3 shows that exposing the egg shell powder to a longer time and higher temperature of calcination results in a lighter white color.

\section{Volume 6 Issue 11, November 2017 www.ijsr.net}




\section{International Journal of Science and Research (IJSR) ISSN (Online): 2319-7064 \\ Index Copernicus Value (2015): 78.96 | Impact Factor (2015): 6.391}

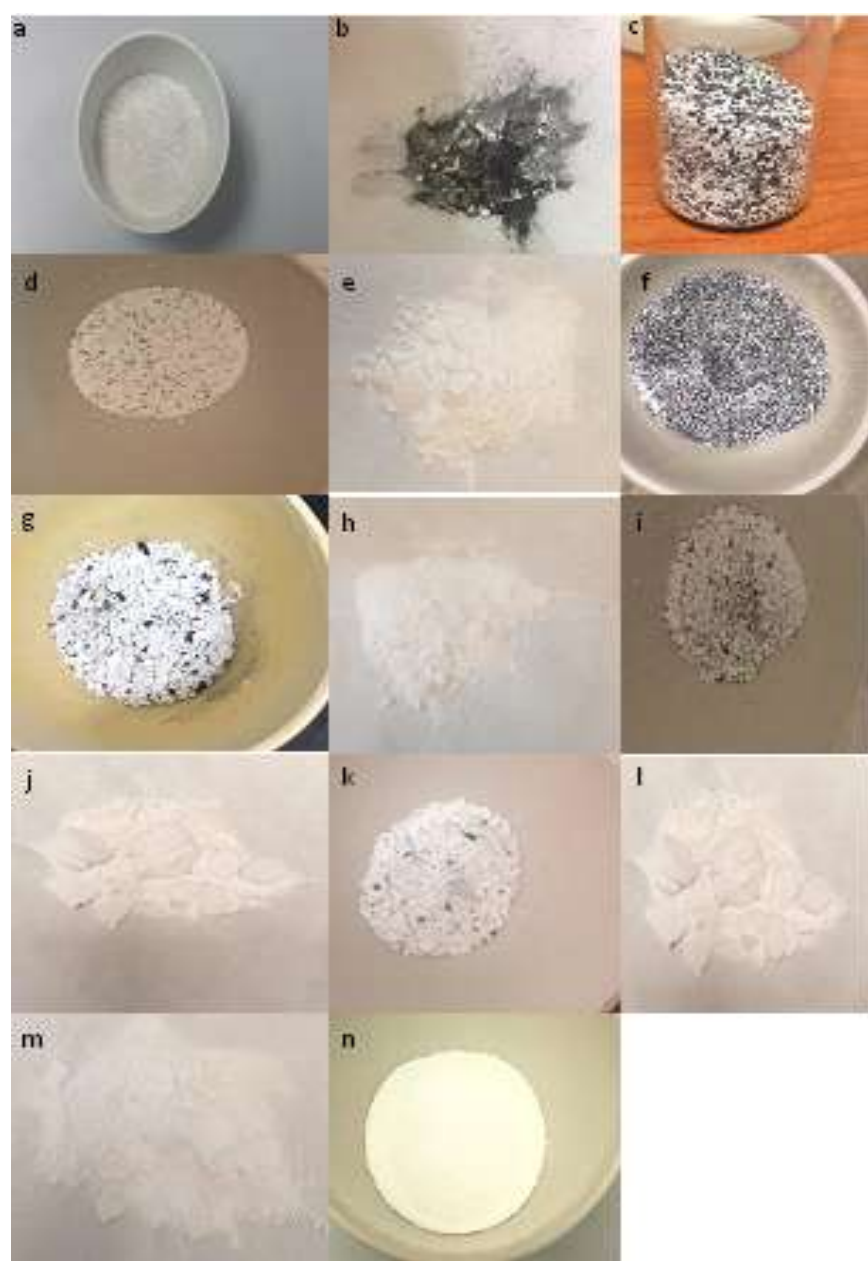

Figure 1: Chicken eggshell powder before and (a) before calcination (b) $700^{\circ} \mathrm{C}$ for $1-2 \mathrm{~h} \mathrm{(c)} 700^{\circ} \mathrm{C}$ for $3 \mathrm{~h}(\mathrm{~d}) 700^{\circ} \mathrm{C}$ for $4 \mathrm{~h}(\mathrm{e}) 700^{\circ} \mathrm{C}$ for $5 \mathrm{~h}(\mathrm{f}) 750^{\circ} \mathrm{C}$ for $1-2 \mathrm{~h}(\mathrm{~g}) 750^{\circ} \mathrm{C}$ for 3 $4 \mathrm{~h}(\mathrm{~h}) 750^{\circ} \mathrm{C}$ for $5 \mathrm{~h} \mathrm{(i)} 800^{\circ} \mathrm{C}$ for $1-2 \mathrm{~h} \mathrm{(j)} 800^{\circ} \mathrm{C}$ for $3-5 \mathrm{~h} \mathrm{(k)}$ $850^{\circ} \mathrm{C}$ for $1 \mathrm{~h}(1) 850^{\circ} \mathrm{C}$ for $2-5 \mathrm{~h}(\mathrm{~m}) 900^{\circ} \mathrm{C}$ for $1 \mathrm{~h}(\mathrm{n}) 900^{\circ} \mathrm{C}$ for $2-5 h$

Table 3: Chicken eggshell powder after calcination

\begin{tabular}{|c|c|c|}
\hline $\begin{array}{c}\text { Calcination } \\
\text { Temperature }\left({ }^{\circ} \mathrm{C}\right)\end{array}$ & $\begin{array}{c}\text { Calcination } \\
\text { time }(\mathrm{h})\end{array}$ & color \\
\hline 700 & 1,2 & Black mixed with gray \\
\hline 700 & 3 & White with gray \\
\hline 700 & 4 & White with little gray \\
\hline 700 & 5 & white \\
\hline 750 & 1,2 & White with gray \\
\hline 750 & 3,4 & White with little gray \\
\hline 750 & 5 & white \\
\hline 800 & 1,2 & White with little gray \\
\hline 800 & 3,4, and 5 & white \\
\hline 850 & 1 & White with little gray \\
\hline 850 & 2,5 & white \\
\hline 900 & 1 & White with little gray \\
\hline 900 & 2,5 & white \\
\hline
\end{tabular}

The scanning electron microscope (SEM) was used to observe the microstructure of eggshell powders calcined at different temperatures and different periods of time. The eggshell before calcination had macro- pores and an irregular crystal structure, SEM images showed that the structure of eggshell changed with calcination temperatures and time. It was observed that eggshells calcined at $700{ }^{\circ} \mathrm{C}$ for $1,2,3$, and $4 \mathrm{hr}, 750{ }^{\circ} \mathrm{C}$ for 1 and $2 \mathrm{hr}$ and $800{ }^{\circ} \mathrm{C}$ at 1 $\mathrm{hr}$ possessed particle's size and shape similar to the eggshell before calcination which is less-porous or even non porous as shown in Figure 2. It was found that calcined samples at the above temperatures were not efficient as $\mathrm{CaO}$ catalyst and have a low catalyst activity.

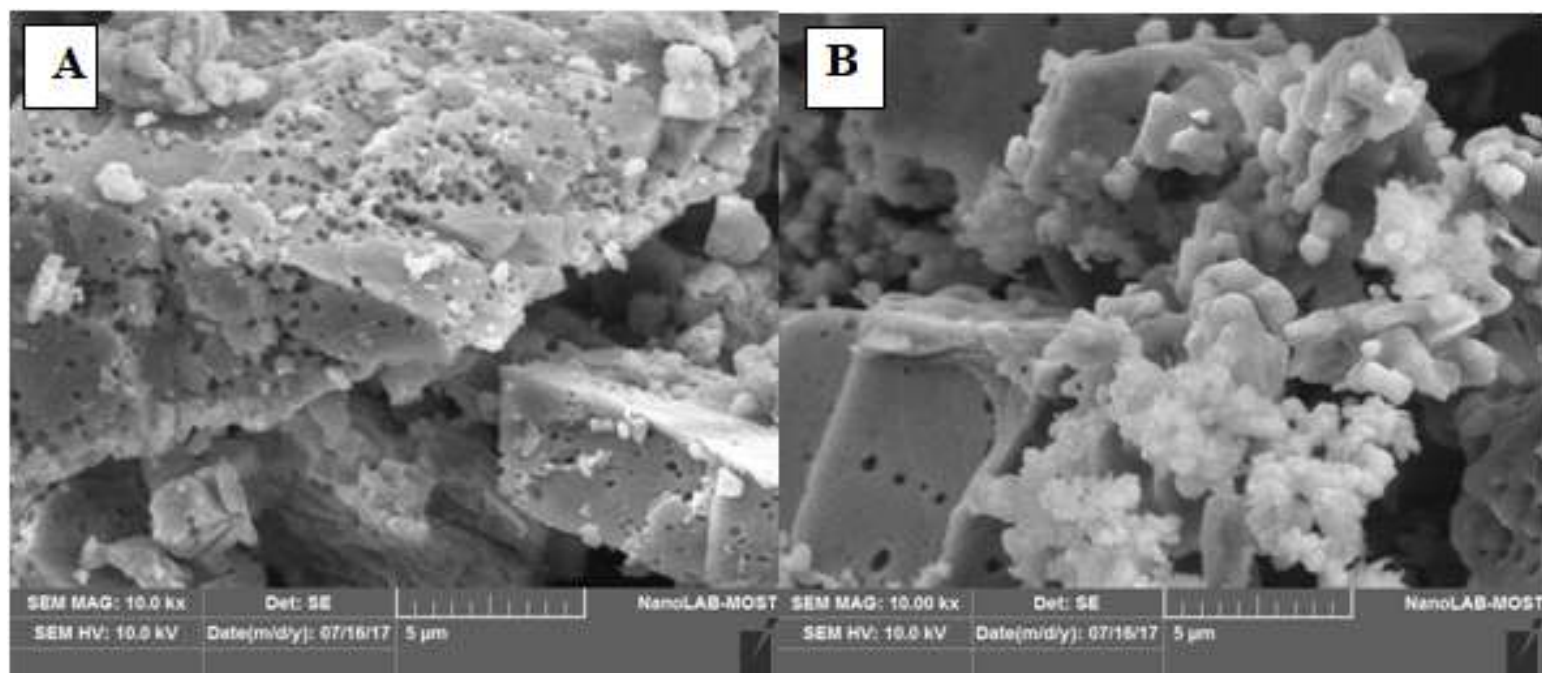

Figure 2: SEM image of (a)eggshells before calcination (b) eggshell after calcination at $700^{\circ} \mathrm{C}$ for $2 \mathrm{hr}$

Different microstructures were observed at $700{ }^{\circ} \mathrm{C}$ for $5 \mathrm{hr}$, $750{ }^{\circ} \mathrm{C}$ for 3,4 , and $5 \mathrm{hr}, 800^{\circ} \mathrm{C}$ for $2,3,4$, and $5 \mathrm{hr}, 850$ and $900^{\circ} \mathrm{C}$ for $1,2,3,4$, and $5 \mathrm{hr}$. The shape of the particle became more uniform and spherical and tended to agglomerate into lumps as shown in Figure 3. This can be attributed to the fact that calcination at the above conditions produced oxide phase and changed the composition of solid cured [29]. Figure 3 shows that large agglomerates and clusters were formed due to the impact of high temperature and the amount of heat transferred to the sample which caused coalescence between sample particles due cohesion and adhesion phenomena; consequently, decreased particle size. According to Kumar and Ali [30], the smaller size of the grains and aggregates could provide higher specific surface areas.

\section{Volume 6 Issue 11, November 2017 www.ijsr.net}




\section{International Journal of Science and Research (IJSR) \\ ISSN (Online): 2319-7064}

Index Copernicus Value (2015): 78.96 | Impact Factor (2015): 6.391
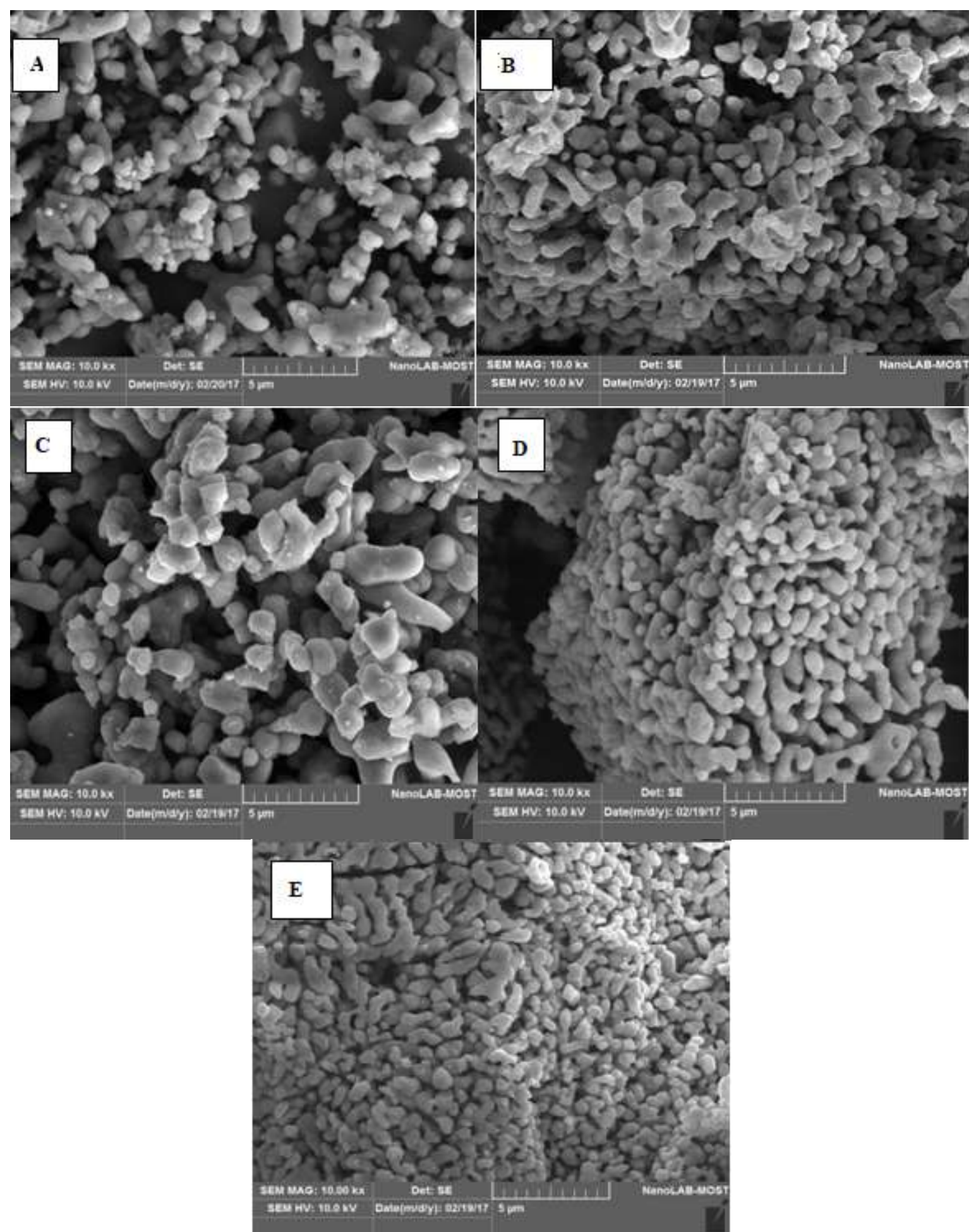

Figure 3: SEM image of the eggshell calcined at (a) $800^{\circ} \mathrm{C}$ for $3 \mathrm{hr}$. (b) at $900{ }^{\circ} \mathrm{C}$ for $3 \mathrm{hr}$. (c) at $700{ }^{\circ} \mathrm{C}$ for $5 \mathrm{hr}$. (d) at $750{ }^{\circ} \mathrm{C}$ for $3 \mathrm{hr}$. (e) at $850{ }^{\circ} \mathrm{C}$ for $3 \mathrm{hr}$

The XRD pattern of $\mathrm{CaO}$ catalyst at different calcination temperatures and periods of time is presented in Figure 4. It is observed that calcination resulted in a phase change of three calcium compounds, $\mathrm{CaO}, \mathrm{CaCO}_{3}$ and $\mathrm{Ca}(\mathrm{OH})_{2}$. The diffraction peaks at $2 \theta$ of $32.2,37.39,53.9$, and 64.7 were the characterizations of $\mathrm{CaO}$, the peaks obtained at $2 \theta$ equal to $3.1,29.4,36.05,39.4,43.2,48.6,57.5$, and 60.8 were for $\mathrm{CaCO}_{3}$ and the peaks appeared at $2 \theta=47.1$ was in $\mathrm{Ca}$
(OH) 2. All catalyst samples showed clear, narrow and well identified peaks. The XRD analysis demonstrated that $\mathrm{CaCO}_{3}$ is the main component of the catalyst at $700{ }^{\circ} \mathrm{C}$ for 1,2 and $3 \mathrm{hr}, 750{ }^{\circ} \mathrm{C}$ at 1 and $2 \mathrm{hr}$, and $800{ }^{\circ} \mathrm{C}$ at $1 \mathrm{hr}$. However, at $700{ }^{\circ} \mathrm{C}$ at 4 and $5 \mathrm{hr} ; 750{ }^{\circ} \mathrm{C}$ at 3,4 , and $5 \mathrm{hr}$; $800^{\circ} \mathrm{C}$ at $2,3,4$, and $5 \mathrm{hr} ; 850$ and $900^{\circ} \mathrm{C}$ at $1,2,3,4$, and 5 $\mathrm{hr} \mathrm{CaO}$ is the main phase presented since all $\mathrm{CaCO}_{3}$ as decomposed to $\mathrm{CaO}[14]$.

Volume 6 Issue 11, November 2017 www.ijsr.net 


\section{International Journal of Science and Research (IJSR) \\ ISSN (Online): 2319-7064}

Index Copernicus Value (2015): 78.96 | Impact Factor (2015): 6.391

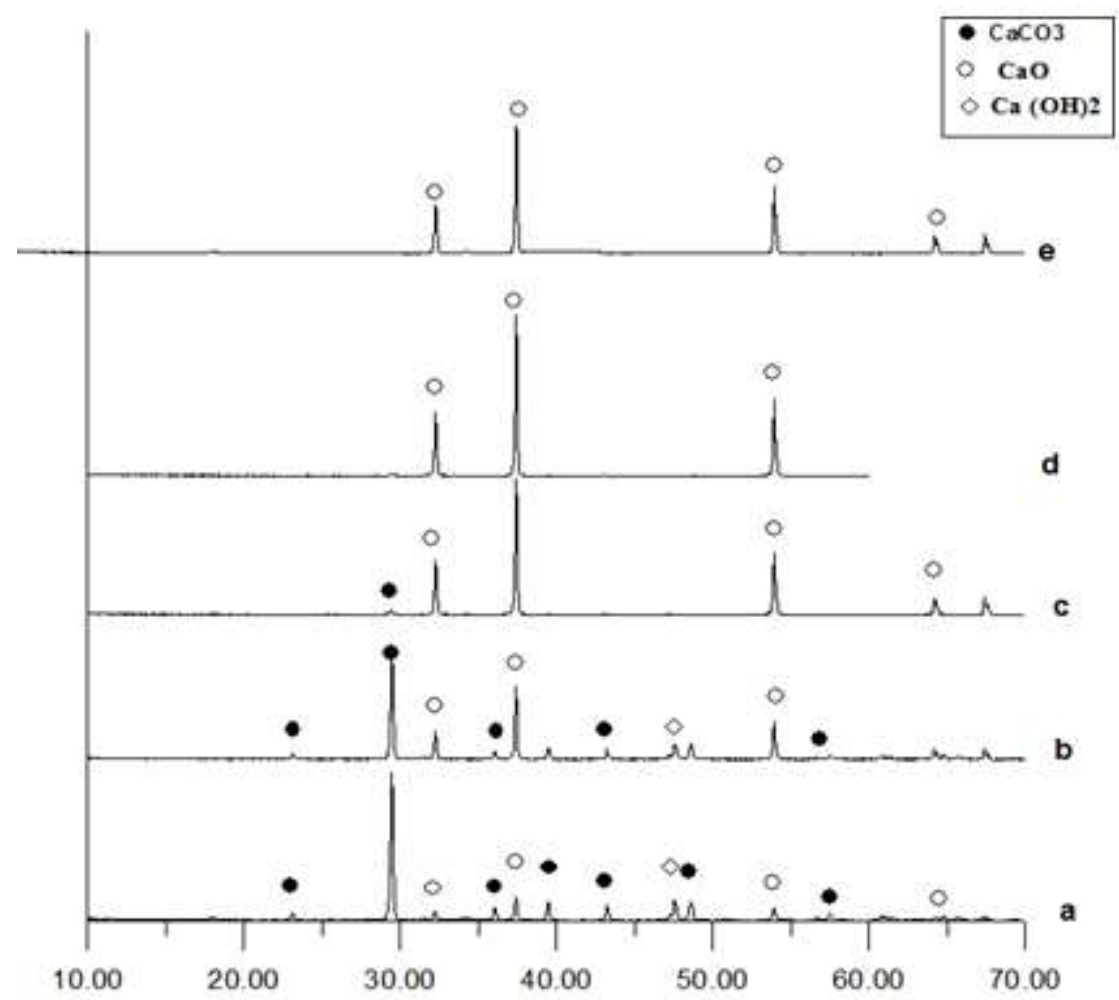

Figure 4: X-ray diffraction pattern of the eggshells after Calcined at Various Temperature (a) $700{ }^{\circ} \mathrm{C}$ for $2 \mathrm{hr}$. (b) $750{ }^{\circ} \mathrm{C}$ for $2 \mathrm{hr}$.(c) $800{ }^{\circ} \mathrm{C}$ for $2 \mathrm{hr}$. (d) $850{ }^{\circ} \mathrm{C}$ for $2 \mathrm{hr}$. (e) $900{ }^{\circ} \mathrm{C}$ for $2 \mathrm{hr}$

Surface area analysis, BET, of the eggshell calcined at different temperature is presented in Table 4. It clearly proves the findings obtained by SEM and XRD tests that calcination at specific temperatures resulted in a higher active surface area [19].

Table 4: BET surface area (SBET), and total pore volume of the waste shell-derived catalyst calcined at different calcination temperatures and time.

\begin{tabular}{|c|c|c|c|}
\hline $\begin{array}{c}\text { Calcination } \\
\text { Temp. }\end{array}$ & $\begin{array}{c}\text { Calcination } \\
\text { Time }\end{array}$ & $\begin{array}{c}\text { Surface area } \\
\left(\mathrm{m}^{2} / \mathrm{g}\right)\end{array}$ & $\begin{array}{c}\text { Por. Vol. } \\
\left(\mathrm{Cm}^{3} / \mathrm{g}\right)\end{array}$ \\
\hline 700 & $3 \mathrm{hr}$. & nil & - \\
\hline 700 & $4 \mathrm{hr}$. & 5.6 & 0.0027 \\
\hline 700 & $5 \mathrm{hr}$. & 4.4 & 0.0021 \\
\hline 750 & $1 \mathrm{hr}$. & 1.18 & - \\
\hline 750 & $2 \mathrm{hr}$. & 1.2 & - \\
\hline 750 & $5 \mathrm{hr}$. & 1.2 & - \\
\hline 800 & $2 \mathrm{hr}$. & 1 & - \\
\hline 800 & $3 \mathrm{hr}$. & 2 & - \\
\hline 800 & $5 \mathrm{hr}$. & 1.1 & - \\
\hline 850 & $1 \mathrm{hr}$. & 0.9 & 0.01 \\
\hline 850 & $3 \mathrm{hr}$. & 9.5 & - \\
\hline 850 & $5 \mathrm{hr}$. & 1.4 & - \\
\hline 900 & $1 \mathrm{hr}$. & 4.7 & 0.0022 \\
\hline 900 & $3 \mathrm{hr}$. & 12.5 & 0.0033 \\
\hline 900 & $5 \mathrm{hr}$. & 0.7 & - \\
\hline
\end{tabular}

3.2 Effect of calcination temperatures and periods of time on catalyst activity

FAMEs' concentration produced was used an indication to determine the influence of calcination temperature and period of time on catalytic activity of the eggshells in the transesterification reaction of WCSO. The experimental results showed that the samples of eggshells calcined for 1 and 2 hrhaveinsignificant catalytic activity at all temperatures of calcination. However, calcination for 3,4, and $5 \mathrm{hr}$ resulted in good activities throughout the reaction. Calcination at $700{ }^{\circ} \mathrm{C}$ for 1,2 , and $3 \mathrm{hr} ; 750{ }^{\circ} \mathrm{C}$ for 1,2 , and $3 \mathrm{hr}$; $800{ }^{\circ} \mathrm{C}$ for 1 , and $2 \mathrm{hr} ; 850{ }^{\circ} \mathrm{C}$ for 1 and $2 \mathrm{hr}$; and 900 ${ }^{\circ} \mathrm{C}$ for 1 and $2 \mathrm{hr}$ produced FAMEs \% of less than 30 . Giving more time for calcination with temperature increase resulted in much better activity; $700{ }^{\circ} \mathrm{C}$ at 4 and $5 \mathrm{hr}, 750{ }^{\circ} \mathrm{C}$ at 4 , and $5 \mathrm{hr}, 800^{\circ} \mathrm{C}$ at 3,4 , and $5 \mathrm{hr}, 850$ and $900^{\circ} \mathrm{C}$ at 3,4 , and $5 \mathrm{hr}$ yielded $70-96 \%$ FAMEs. The optimum catalyst performance was obtained at $900{ }^{\circ} \mathrm{C}$ for $3 \mathrm{~h}$ which corresponds to SBET of $12.5 \mathrm{~m} 2 /$ gram.

3.3 Influence of operating conditions on the transesterification of WCSO over eggshell waste derived catalyst

The prepared $\mathrm{CaO}$ catalyst was used as a solid catalyst for the transesterification of WCSO. The FAMEs content was affected by the reaction conditions $[20,22,31]$. To obtain a higher yield of FAMEs, the reaction conditions were changed and the optimum operating conditions were verified. The transesterification reaction was carried out over the catalyst calcined at $900 \mathrm{C}$ for $3 \mathrm{hrs}$ at different methanol. This seems like something that you might want to reword. There seems like there should be something more like "different levels of methanol" or different amounts of methanol" or something like that.):WCSO ratio, time of reaction, temperature of reaction and catalyst loading.

Formation of biodiesel depends on the excessive amount of methanol where the reaction is reversible reaction [7]. As shown in Figure 5, when methanol is increased, the WCSO ratio has an adverse impact on FAMEs yield, while

\section{Volume 6 Issue 11, November 2017}




\section{International Journal of Science and Research (IJSR) \\ ISSN (Online): 2319-7064 \\ Index Copernicus Value (2015): 78.96 | Impact Factor (2015): 6.391}

the maximum yield was obtained at 30. Figure 6 presents the influence of catalyst loading on the conversion of WCSO. A loading of less than $4 \mathrm{wt} \%$ would result in a poor yield. However, FAMEs yield increases by increasing the catalyst loading to more than $5 \mathrm{wt} \%$ which is a critical point that leads to forming a slurry in the reaction mixture. It has also been noticed that yield increases to $96.11 \%$ when the catalyst loading increases to $5 \mathrm{wt} \%$ at $3 \mathrm{~h}$, then declined at higher catalyst loading at the same reaction time. This can be attributed to the fact that the solubility of methanol in WCSO is low and increasing catalyst loading provides more active sites to adsorb the products; consequently, the yield of biodiesel decreases.

Because of being a reversible reaction, the transesterification reaction needs a longer time to approach equilibrium state. The effect of reaction time was examined at 1,2, 3, and 4 hr. Figure 7 depicts the impact of time on stream on FAMEs yield. As clearly seen, a yield of $96.11 \%$ is achieved at $3 \mathrm{hr}$ and decreases to $91.45 \%$ at $4 \mathrm{hrs}$. Actually, increasing the time of reaction enhances the residence time of WCSO with methanol, thus producing more FAMEs. However, prolonged time of reaction results in adsorption of products on the active catalytic site and givesa lower FAMES yield.

To illustrate the influence of temperature upon the yield of FAMEs, the experimental data are plotted in Figure 8. Although high reaction temperature increases FAMEs yield, for economic reasons, it is favorable to carry out the reaction at a lower temperature of methanol reflux. Figure 8 shows that at $3 \mathrm{~h}, 5 \mathrm{wt} \%$ catalyst loading, 30:1 methanol: WCSO and $65{ }^{\circ} \mathrm{C}$, FAMEs yield is $96.11 \%$, while at $55^{\circ} \mathrm{C}$ and $60{ }^{\circ} \mathrm{C}$, FAMEs yields are $37.33 \%$ and $82.64 \%$ respectively. The general behavior is, higher yield is achieved at higher temperatures because of high temperature, and the transtesterification rate constant are favorably affected resulting in increasing in reactant conversion. However, carrying out this reversible reaction at higher reaction temperature of $70{ }^{\circ} \mathrm{C}$ formed undesired products through oligomerization reaction, which resulted in the hindrance of FAME formation and the yield decreased to $68.12 \%$.

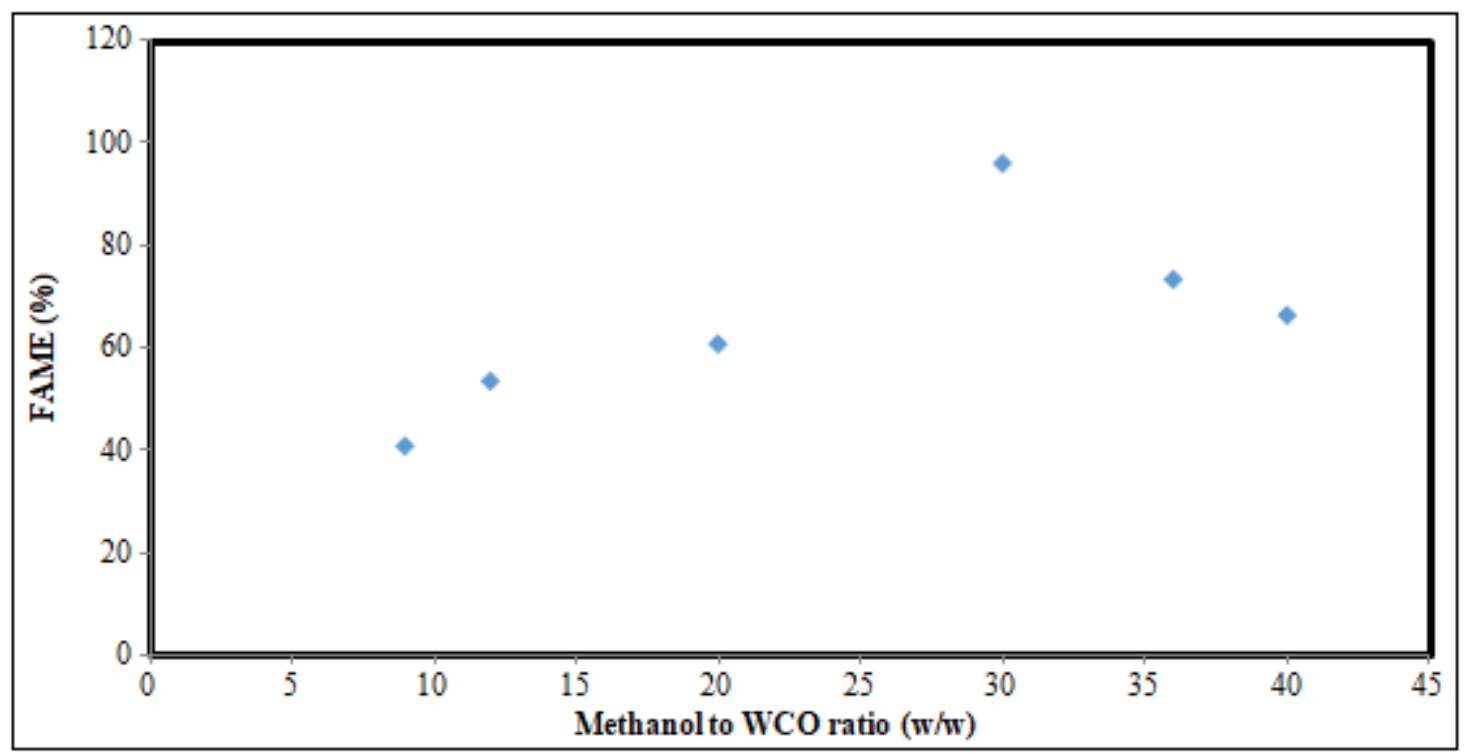

Figure 5: Effect of methanol to oil molar ratio on FAME content, at $65^{\circ} \mathrm{C}, 3 \mathrm{~h}, 5 \mathrm{wt} \%$ and $300 \mathrm{rpm}$.

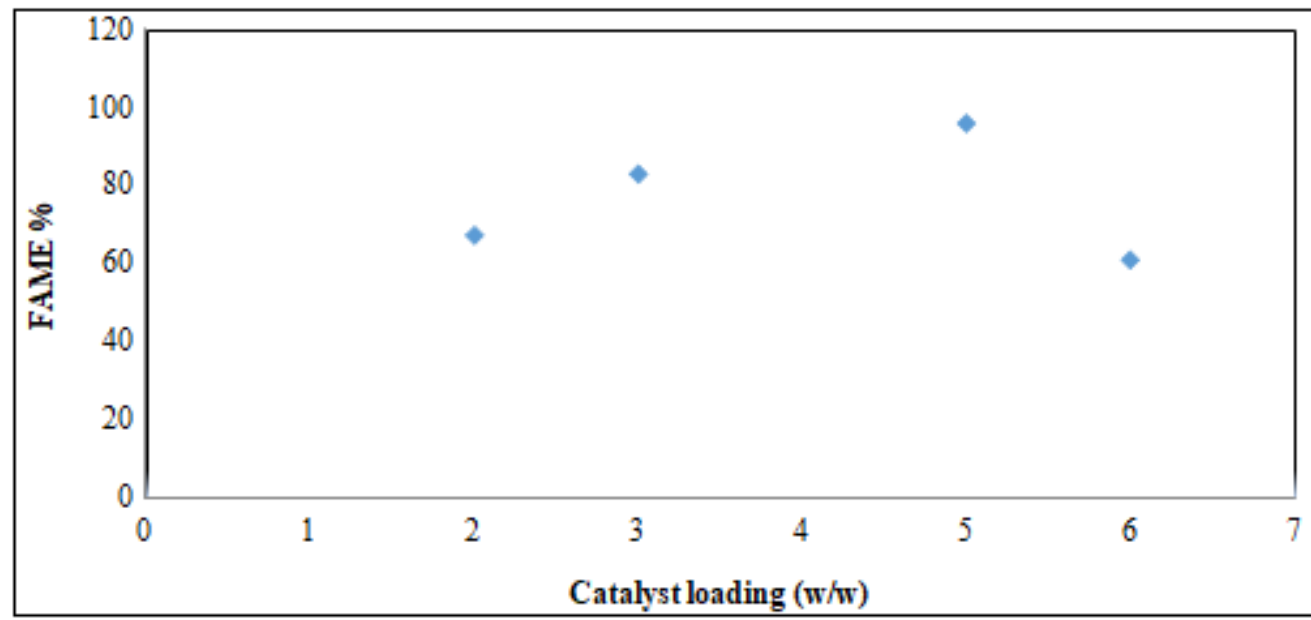

Figure 6: Effect of catalyst loading on FAME content, at $65^{\circ} \mathrm{C}, 3 \mathrm{~h}, 30: 1$ and $300 \mathrm{rpm}$.

Volume 6 Issue 11, November 2017 www.ijsr.net 
International Journal of Science and Research (IJSR)

ISSN (Online): 2319-7064

Index Copernicus Value (2015): 78.96 | Impact Factor (2015): 6.391

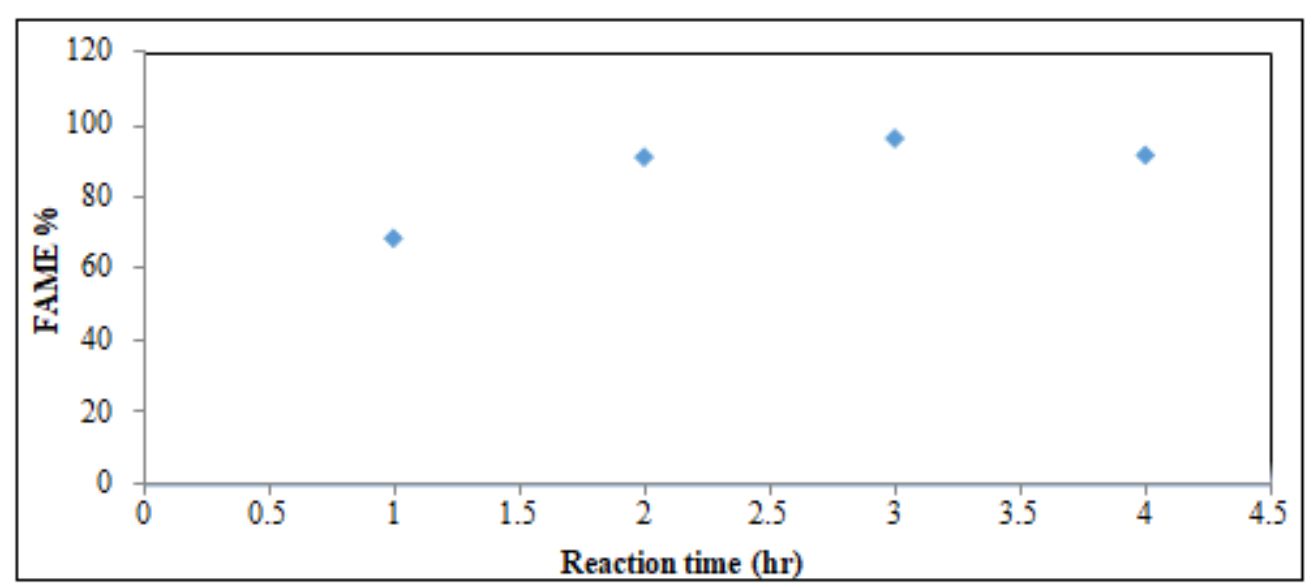

Figure 7: Effect of reaction time on FAME content, at $65^{\circ} \mathrm{C}, 5 \mathrm{wt} \%, 30: 1$ and $300 \mathrm{rpm}$

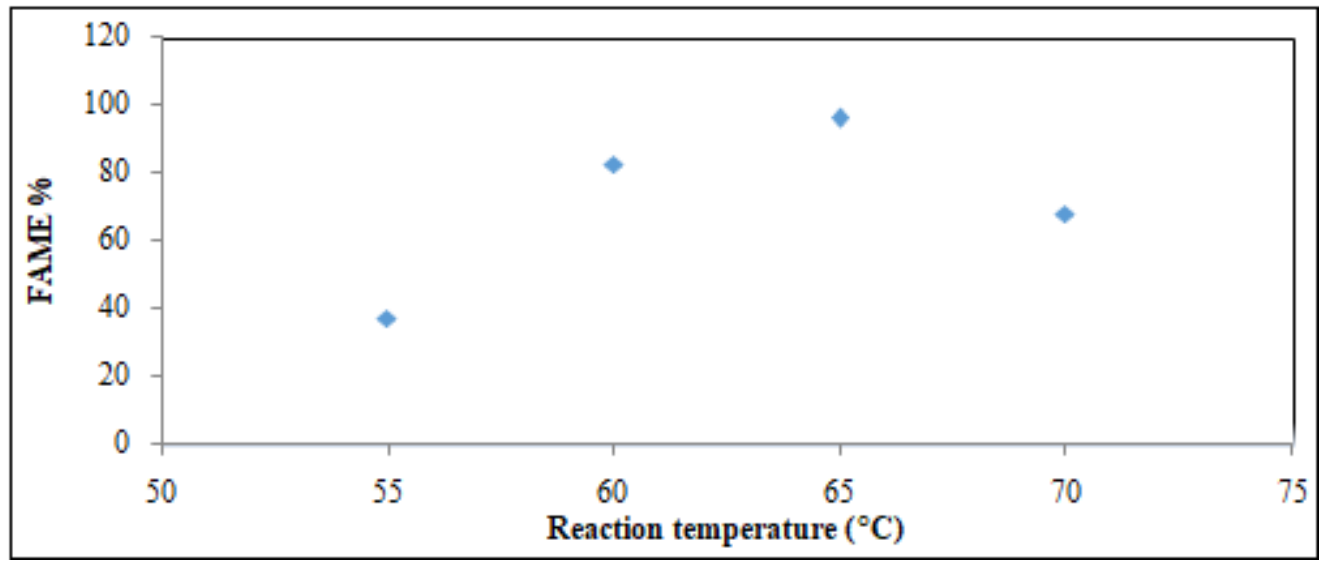

Figure 8: Effect of reaction temperature on FAMEs content, at $3 \mathrm{~h}, 5 \mathrm{wt} \%, 30: 1$ and $300 \mathrm{rpm}$

\subsection{Reusability of eggshell waste derived catalyst}

One of the most important features for a heterogeneous catalyst is the ability to be recycled. Reusability of $\mathrm{CaO}$ catalyst obtained by the calcination at the optimum conditions concluded in this study was examined with 5 wt $\%$ catalyst loading (based on oil weight), a methanol to oil ratio of $30: 1$, a reaction temperature of $65{ }^{\circ} \mathrm{C}$ and a reaction time of $3 \mathrm{~h}$. Figure 9 shows the performance of the prepared catalyst in 3 cycles. After each cycle, the solid catalyst was separated from the reaction mixture by filtration and washed with n-hexane to remove the adsorbed stains without further treatment. In the range of these experiments, FAMEs yield decreased by increasing the number of cycles as illustrated in Figure 9. It has also been observed that FAMEs yield decreases from $96.11 \%$ for the fresh catalyst to $82.31 \%$ for the third use catalyst. This can be attributed to the fact that WCSO molecules coverage the active site over the catalyst surface and/or proves that catalyst deactivation take place. The deactivation of eggshell- derived catalyst may also be attributed to phase change which is proved by FT-IR pattern shown in Figure 10. In this pattern, $\mathrm{CaO}$ spectra was obtained for the fresh catalyst (green line) and the third use catalyst (red color). However, the catalyst can be regenerated to recover the original pattern by routine calcination.

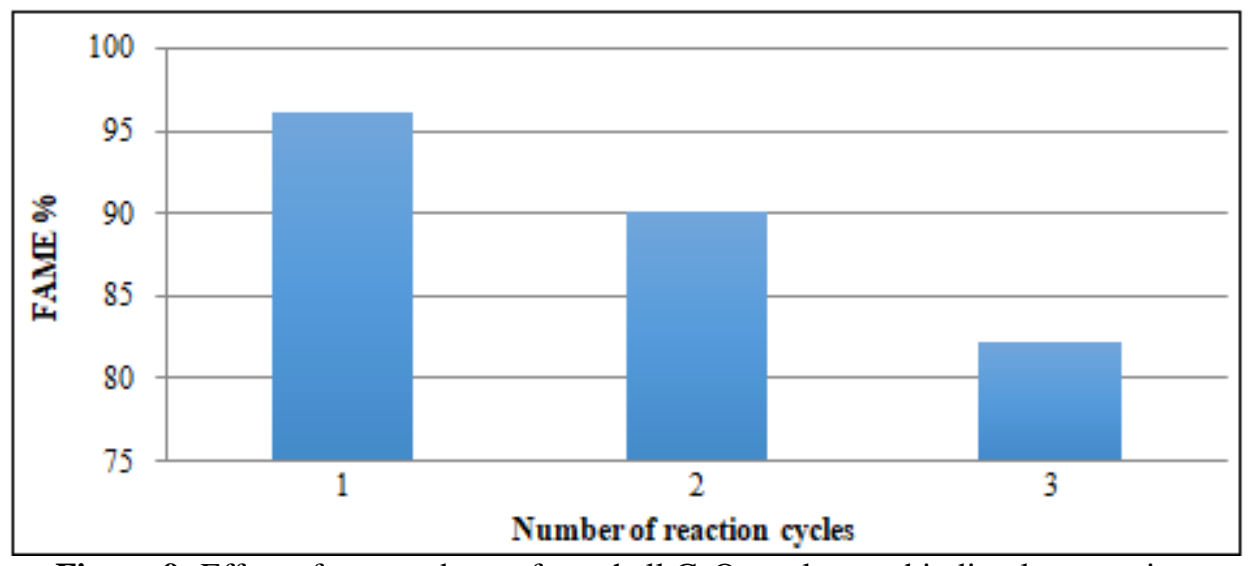

Figure 9: Effect of repeated use of eggshell $\mathrm{CaO}$ catalyst on biodiesel conversion

Volume 6 Issue 11, November 2017 www.ijsr.net 
International Journal of Science and Research (IJSR)

ISSN (Online): 2319-7064

Index Copernicus Value (2015): 78.96 | Impact Factor (2015): 6.391

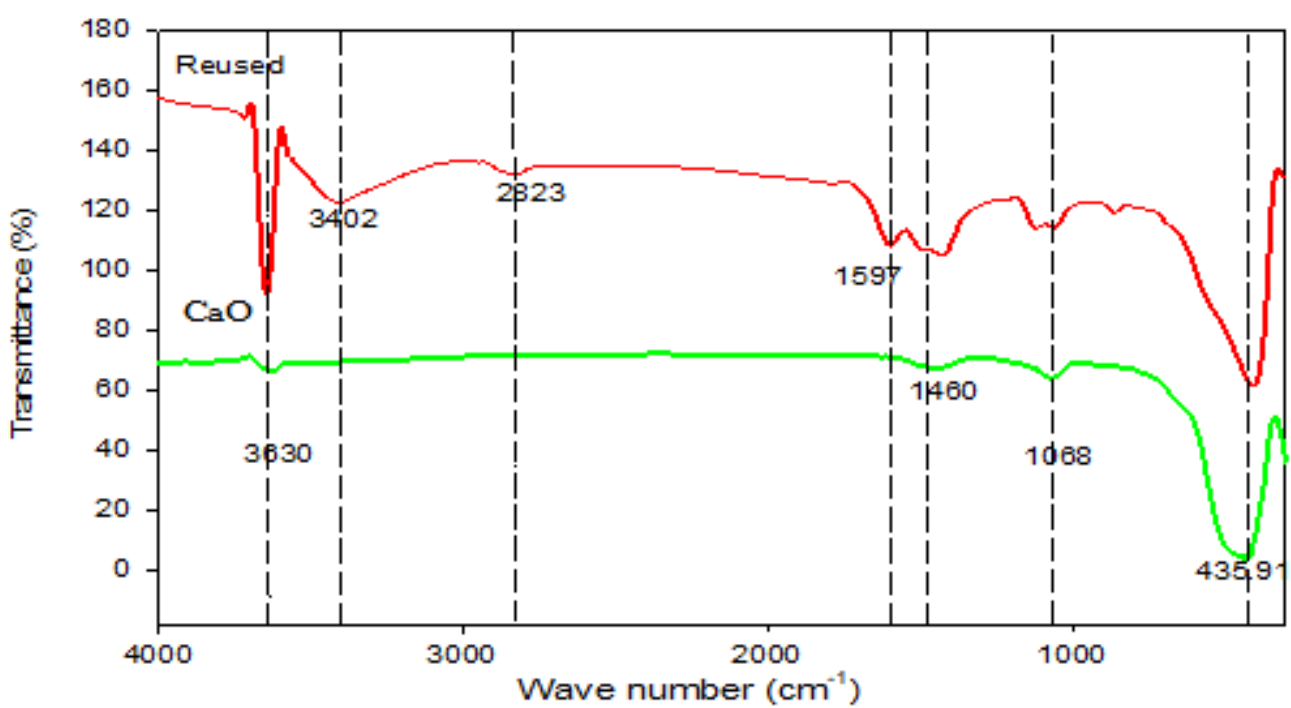

Figure 10: FTIR spectra of fresh $\mathrm{CaO}$ catalyst after the third cycle

\section{Conclusion}

The present study has successfully reported the utilization of local eggshells to derive calcium oxide catalyst for the transesterification of waste cooking sunflower oil. The optimum calcination conditions were obtained by careful examination of eggshell powders with XRD, SEM and BET tests and confirmed at $900{ }^{\circ} \mathrm{C}$ for $3 \mathrm{~h}$. It showed a high active surface area of $12.8 \mathrm{~m} 2 / \mathrm{gm}$ and aggregate like lumps with almost a pure calcium oxide phase. The optimum operation conditions were found to be $65 \mathrm{C}$ temperature, 3 hrs reaction time, methanol: WCSO molar ratio of $30: 1$, catalyst loading of $5 \mathrm{wt} \%$ and stirring speed $300 \mathrm{rpm}$ yielded $96.11 \%$ of biodiesel. The catalyst had excellent activity in promoting the transesterification of WCSO containing $96.22 \%$ fatty acids, to biodiesel production. It is very helpful to note that WCO was applied without any esterification pretreatment. Additionally, the reuse of the cheap eggshell derived catalyst for three times at the optimum conditions revealed significant, but small decay of biodiesel yield due to the loss or blockage of active sites via side reactions or adsorption of products. The fuel specifications of FAMEs compounds were found to be closely in accordance with biodiesel standards prescribed by EN14103. Therefore, the waste eggshell derived $\mathrm{CaO}$ catalyst was found to be efficient, stable and cost-effective heterogeneous catalyst for biodiesel production.

\section{Acknowledgment}

We wish to specially acknowledge the assistance offered by the University of Baghdad AL Khwarizmi College of Engineering for carrying out this investigation

\section{References}

[1] Thanh Le Tu, Kenji Okitsu, Luu Van Boi and Yasuaki Maeda. Catalytic Technologies for Biodiesel Fuel Production and Utilization of Glycerol: A Review Catalysts, 2012, 2, 191-222; doi:10.3390/catal 2010191.

[2] Olutoye, M.A., et al., Synthesis of FAME from the methanolysis of palm fatty acid distillate using highly active solid oxide acid catalyst. Fuel Processing Technology, 2014. 124: p. 54-60.

[3] Wan, Z., J.K. Lim, and B.H. Hameed, Chromiumtungsten heterogeneous catalyst for esterification of palm fatty acid distillate to fatty acid methyl ester. Journal of the Taiwan Institute of Chemical Engineers, 2015. 54: p. 64-70.

[4] Mansir, N., et al., Investigation of heterogeneous solid acid catalyst performance on low grade feedstocks for biodiesel production: A review. Energy Conversion and Management, 2016.

[5] Amani, H., et al., Transesterification of waste cooking palm oil by $\mathrm{MnZr}$ with supported alumina as a potential heterogeneous catalyst. Journal of Industrial and Engineering Chemistry, 2014. 20(6): p. 44374442.

[6] Mahesh, S.E., et al., Biodiesel production from waste cooking oil using $\mathrm{KBr}$ impregnated $\mathrm{CaO}$ as catalyst. Energy Conversion and Management, 2015. 91: p. 442-450.

[7] Amani, H., Z. Ahmad, and B.H. Hameed, Highly active alumina-supported $\mathrm{Cs}-\mathrm{Zr}$ mixed oxide catalysts for low-temperature transesterification of waste cooking oil. Applied Catalysis A: General, 2014. 487: p. 16-25.

[8] Boey, P.-L., G.P. Maniam, and S.A. Hamid, Performance of calcium oxide as a heterogeneous catalyst in biodiesel production: A review. Chemical Engineering Journal, 2011. 168(1): p. 15-22.

[9] Kouzu, M. and J.-s. Hidaka, Transesterification of vegetable oil into biodiesel catalyzed by CaO: A review. Fuel, 2012. 93: p. 1-12.

[10] Vikram Kumar a, Muthusivaramapandian Muthuraj b,1, Basavaraj Palabhanvi b,1, and D.D.a. Aloke Kumar Ghoshal a,Evaluation and optimization of two stage sequential in situtransesterification process for fatty acid methyl ester quantification from microalgae. Renewable Energy, 2014. 68: p. 560-569.

[11] Degirmenbasi, N., N. Boz, and D.M. Kalyon, Biofuel production via transesterification using sepiolitesupported alkaline catalysts. Applied Catalysis B: Environmental, 2014. 150-151: p. 147-156.

\section{Volume 6 Issue 11, November 2017}




\section{International Journal of Science and Research (IJSR) \\ ISSN (Online): 2319-7064}

Index Copernicus Value (2015): 78.96 | Impact Factor (2015): 6.391

[12] Lam, M.K., K.T. Lee, and A.R. Mohamed, Homogeneous, heterogeneous and enzymatic catalysis for transesterification of high free fatty acid oil (waste cooking oil) to biodiesel: a review. Biotechnol Adv, 2010. 28(4): p. 500-18.

[13] Koberg, M. and A. Gedanken, Direct Transesterification of Castor and Jatropha Seeds for FAME Production by Microwave and Ultrasound Radiation Using a SrO Catalyst. BioEnergy Research, 2012. 5(4): p. 958-968.

[14] Tan Yie Hua, Mohammad Omar Abdullah, Cirilo Nolasco-Hipolito, Yun Hin Taufiq-Yap. Waste ostrichand chicken-eggshells as heterogeneous base catalyst for biodiesel production from used cooking oil: Catalyst characterization and biodiesel yield performance. Applied Energy 160 (2015) 58-70

[15] Piker, A., et al., A green and low-cost room temperature biodiesel production method from waste oil using egg shells as catalyst.Fuel, 2016. 182: p. 3441.

[16] Colombo, K., L. Ender, and A.A.C. Barros, The study of biodiesel production using $\mathrm{CaO}$ as a heterogeneous catalytic reaction.Egyptian Journal of Petroleum, 2016.

[17] Viola, E., et al., Biodiesel from fried vegetable oils via transesterification by heterogeneous catalysis. Catalysis Today, 2012.179(1): p. 185-190.

[18] Kesic Željka, I.L., Miodrag Zdujic, Ljiljana Mojovic1, Dejan Skala1, Calcium oxide based catalysts for biodiesel production: a review. Chem. Ind. Chem. Eng. Q . 22 (4) 391-408 (2016)

[19] Sirisomboonchai Suchada, Maidinamu Abuduwayiti, Guoqing Guan, Chanatip Samart. Biodiesel production from waste cooking oil using calcined scallop shell as catalyst. Energy Conversion and Management, 2015. 95; 242-247.

[20] Shawket Abliz, Xiaogang Hao, Katsuki Kusakabe, Abuliti Abudula. Biodiesel production from waste cooking oil using calcined scallop shell as catalyst. Energy Conversion and Management 95 (2015) 242247.

[21] Pandit Priti R., Fulekar M.H. Egg shell waste as heterogeneous nanocatalyst for biodiesel production: Optimized by response surface methodology. Journal of Environmental Management 198 (2017) 319-329.

[22] Teo Siow Hwa, Aminul Islam, Hamid Reza Fard Masoumi, Yun Hin Taufiq-Yap, Jidon Janaun, EngSeng Chan, M.A. khaleque Effective synthesis of biodiesel from Jatropha curcas oil using betaine assisted nanoparticle heterogeneous catalyst from eggshell of Gallus domesticus. Renewable Energy 111 (2017) 892-905.

[23] Viriya-empikul N., P. Krasae, B. Puttasawat, B. Yoosuk, N. Chollacoop, K. Faungnawakij. Waste shells of mollusk and egg as biodiesel production catalysts. Bioresource Technology 101 (2010) 37653767.

[24] Boro Jutika, Lakhya Jyoti Konwar, Dhanapati Deka. Transesterification of non edible feedstock with lithium incorporated eggshell derived $\mathrm{CaO}$ for biodiesel production. Fuel Processing Technology 122 (2014) 72-78.
[25] Niju S ., Meera K.M. S. Begum, N. Anantharaman. Modification of egg shell and its application in biodiesel production. Journal of Saudi Chemical Society (2014) 18, 702-706

[26] Chen Guanyi, Rui Shan, Jiafu Shi, Beibei Yan. Ultrasonic-assisted production of biodiesel from transesterification of palm oil over ostrich eggshellderived $\mathrm{CaO}$ catalysts conversion. Bioresource Technology 171 (2014) 428-432

[27] Gupta Anilkumar R., Suraj V. Yadav, Virendra K. Rathod. Enhancement in biodiesel production using waste cooking oil and calcium diglyceroxide as a heterogeneous catalyst in presence of ultrasound. Fuel 158 (2015) 800-806.

[28] Tan Yie Hua, Mohammad Omar Abdullah, Cirilo Nolasco-Hipolito. The potential of waste cooking oilbased biodiesel using heterogeneous catalyst derived from various calcined eggshells coupled with an emulsification technique:A review on the emission reduction and engine performance. Renewable and Sustainable Energy Reviews 47(2015)589-603

[29] Coen Duvekot. Determination of FAME and linolenic acid methyl ester in biodiesel according to EN-14103. Agilent Technologies Inc.2011.

[30] Wei, Z., C. Xu, and B. Li, Application of waste eggshell as low-cost solid catalyst for biodiesel production. Bioresour Technol, 2009. 100(11): 2883-5.

[31] Kumar D, Ali A. Nanocrystalline $\mathrm{KeCaO}$ for the transesterification of a variety of feedstocks: structure, kinetics and catalytic properties. Biomass Bioenergy 2012; 46:459-468.

[32] Majhi Samrat, Ray Srimanta. A study on production of biodiesel using a novel solid oxide catalyst derived from waste. Environ Sci Pollut Res (2016) 23:92519259 